\title{
Direct Consequence of British Political Diplomacy on African Traditional Structure: A Study of Changes in ILORIN $1895-1915$
}

\author{
Dr. S. Y. Omoiya \\ Department of History and International Studies University of Ilorin Ilorin Nigeria
}

\begin{abstract}
The aftermath of West African Berlin Conference of 1884 -1885 has remained a turning point in the historical reconstruction of most of the traditional African politics. Apart from the fact that it marked the new phase of foreign political domination of the African peoples, it also transformed the African political structures to accommodate the interest of the new masters. In Ilorin Emirate, as it were in most other parts of the traditional Caliphate in Nigeria, the consequences of the European led war of pacification is far reaching. This study is to provide an insight to the changes witnessed in the Ilorin political structure, as direct consequence of British political diplomacy in a part of Africa
\end{abstract}

\section{The Establishment of direct Colonial rule in Ilorin and its attendant consequences}

The appointment and posting of the first British Colonial Resident, David Carnegie to Ilorin in June, 1900 opened a new phase of intra and inter ethnic conflict through power play between the indigenous chieftaincy institutions. For instance, the Balogun Agba, fully supported by the other Balogun jointly expressed their resentments against the arrival of David Carneige as the British Resident in the area because they saw it purely as a foreign domination and an erosion of their power and influence. On the other hand, the Emir was warm towards him (the Resident) Omoiya S.Y. 1988. Certainly, because he neither had any political power nor influence to lose.

These contrasting postures of the Balogun and the peoples' of Ilorin on one hand and that of the Emir on the other, provided good opportunities for the Colonial Resident to exploit the difference between the indigenous ruling class to fashion out the approach to be adopted to make easy the establishment of colonial rule in the area. David Carnegie observed that the Emir was powerless and that the actual rulers in Ilorin Emirate were the Balogun and the other Chiefs. They were said to enjoy the good following of the people. NAK/SNP/15/11 Carnegie to H.E July 1900.

The Colonial Resident quickly took the advantage of the differences between the Ilorin traditional ruling elite to impress on the Colonial High Commissioner, Lord Lugard, to forcefully back the weak, that is, supporting the Emir against the powerful chiefs in Ilorin represented by the Balogun .NAK/SNP/15/11 Carnegie to H.E July 1900.

It was not long when David Carnegie took ill and died. He was replaced by P. Dwyer. Omoiya S.Y. 1988.

In the second Colonial Resident's report of July 1900, he confirmed the enormous powers of the Balogun in the administration of Ilorin Emirate. He went further to say that to his personal knowledge Balogun Inakoju Ali of Alanamu was the actual ruler in Ilorin within the immediate past six years. NAK/SNP/15/11/Dwyer to H/E August, 1900. He then suggested that the only way by which the colonial administration could be established in Ilorin Emirate without much cost, was to depose and deport Balogun Alanamu who was identified to be leading the other Balogun and the people of Ilorin against the establishment of British rule in the area NAK/SNP/15/11/Dwyer to H/E August, 1900. Dwyer also confirmed the mere status of the Emir in the administration of the Emirate. He opined that the deposition and deportation of Balogun Inakoju Ali of Alanamu would be a lesson to the other Balogun to stop their resistance against the establishment of colonial rule. NAK/SNP/15/11/Dwyer to H/E August, 1900.

In the reply to P. Dwyer, the High Commissioner agreed with all the suggestions made by the Resident but advised that he should tarry in the move against Balogun Alanamu, until the arrival of the forces from Asante, before he swung into action. Lugard also advised Dwyer to constantly monitor the movement of Balogun Alanamu, to be able to charge him for an offence and then provide rational grounds for his deposition and deportation. NAK/SNP/15/11 H/E to Dwyer September, 1900.

The Emir, perceiving the British intention to contest the powers of the Balogun, continued to demonstrate loyalty to the British. This support was demonstrated in Bida incident of 1900. In August of that year when Bida was hard pressed by the imperial forces, she sent to Ilorin for military assistance. Obaro Ikime 1977 P. 129. While the Balogun and the people of Ilorin were ready to offer the assistance, the Emir reported 
the incident to the colonial Resident Obaro Ikime 1977 P. 129. The Emir feared that if the resistance of the people of Bida was successful, they might equally grant assistance to the Balogun and the people of Ilorin to drive the British away. Consequently, his treachery will become a case against him. Alh. Saliu Dauda. Oral evidence.

Another chance that showed the pro-British stance of the Emir came from an incident that involved the Caliph in Sokoto. This time, he received a letter from the Caliph in Sokoto, Attairu first, to cause a disturbance in Ilorin so as to divert the attention of the British army from attacking Sokoto at the time Alh. Saliu Dauda. Oral evidence It was likely that the Caliph decided to make the demand on the Emir of Ilorin to be able to have enough time to get prepared for the attack of the British. As custom demanded, the Emir read the Caliph's letter aloud to the people. As he did in the case of Bida, the Emir sent the Caliph's messenger with the letter to the British Resident in Ilorin Alh. Saliu Dauda .Oral evidence. By this act of Emir Sulyman, he had given up the Caliph to the British. The BalogunAgba, the other Balogun and the people of Ilorin maintained a watchful eye on the Emir's relations with the colonial Resident and they were hopeful that time will soon catch up with him. Alh. Sule Salawu. Oral evidence.

From the religious point of view, the acts of Emir Sulyman negate the principle and practice of the Islamic religion. Going by the tenets of the Holy Quran and the Hadith, it is an obligation for a Muslim to resist the leadership of non-Muslims, who are commonly referred to as infidels. The Holy Quran, Chapter 8, verse 65, Also, for a leader of a Muslim community, such as Ilorin, to subscribe to the ruler ship of the British who were non-muslims is totally unIslamic. The Holy Quran, Chapter 8, verse 65,

The friendliness of Emir Sulyman with the Colonial Resident is an illustration of his preference for political power and influence to Islamic reformist interest given by the Jihadists. It thus opened a new phase of inter group relations that was purely motivated by political reasons. This time, between the Emir of Ilorin and the British on one hand, and the Ilorin Traditional Political System led by the Balogun on the other. The personal decision of the Emir to prefer relationships with British agent to his traditional administrative team, clearly illustrates the strong desire of Emirs in Ilorin to rule rather than to reign and serve as mere religious leadership symbol.

On the part of the Balogun, the experience of their encounter with the British led West African Frontier force, which brought about the conquest of Ilorin in 1897 was still very fresh in their memory. This explained why they tried to avoid any form of open confrontation with the British at the time they were in Ilorin to formally establish colonial rule.

\section{The Restructuring of Ilorin Political System}

The full demonstration of Emir Sulyman's support for the British colonial interests was manifested by his non support of the Balogun in Ilorin against the British rule, betrayer of sister Emirates such as Bida and even the caliph in Sokoto. These behaviours of the Emir were certainly meant to convince the colonial administration of his unalloyed support of it. He certainly must have believed that with his loyalty to the British and the British support for him, his traditional status in the administration of Ilorin Emirate will dramatically change from a titular head to a full Emir with authority.

On the part of the British, they have also come to terms with the reality that except they forcefully back the Emir against the Balogun, the penetration and establishment of colonial rule in Ilorin would be impossible. Thus, there began the scheme to arrange an arrest of the leader of the opposition to their rule, strip him of his traditional title and deport him out of Ilorin NAK/SNP/15/11 P. Dwyer to H. C. August 1900. The Colonial government believed its action will not only remove the opposition but that it will also deter other people from opposing its rule NAK/SNP/15/11 Lugard to Dwyer, September, 1900

By 1902 the stage was set, and Balogun Inakoju Ali, the BalogunAgba (Alanamu) became the first victim of the colonial government's schemes to subjugate and subordinate the Balogun who were the actual ruler in Ilorin Emirate as S. Hogben puts it.

The Emir, finding himself backed up by the Resident, broke away from the constraining hands of Alanamu and other chiefs and commenced to act up to his position in a way which showed that he realized how tide had changed. No longer was he figure head shaking in shoes with dread of a sudden death, but an Emir, supported by the Government, who insisted on the payment of tributes Hogben S. J. 1966 pp.161 - 163.

Hogben goes further to narrate how the BalogunAgba, Balogun Inakoju Ali of Alanamu was napped by traps set by the Colonial government. Hogben S. J. 1966 pp.161 - 163. The Balogun was immediately arrested and deported to Jebba, where a contingent of the colonial army was already waiting in preparation for any eventuality that could attend the deposition order Hogben S. J. 1966 pp.161 - 163.

The large group of people who moved from Ilorin to Jebba to see the Balogun and demonstrate their support for his cause made the colonial government appreciates the fact that it was not an issue they could control with mere presence of the army, without resorting to violence. To avoid unnecessary bloodletting, Balogun Inakoju Ali was thus moved from Jebba to Lokoja Omoiya S. Y. 1986 a more distant place from Ilorin. 
It must be appreciated that the Emir represented the minority group, while the Balogun, especially Alanamu and the others represented the majority. The large number of people from different ethnic groups in Ilorin who went to Jebba despite the heavy presence of the colonial army, to forestall any form of violence that could accompany the deposition of Balogun Alanamu, confirmed the popularity of the Balogun.

Apart from the people's demonstration of support for Balogun Inakoju Ali, the actions of the other Balogun and the people totally betrayed the postulations of both the colonial Resident in Ilorin, P. Dwyer and Lord Lugard that the removal of Balogun Inakoju Ali of Alanamu, would prevent others from formenting any further trouble. The other Balogun instructed their people to ignore both the Colonial Resident and the Emir by not cooperating with the colonial instructions passed through the Emir. Omoiya S. Y. 1986. The failure of colonial administration to realize the anticipated peace by the dethronement of Balogun Inakoju Ali, the Balogun Agba in Ilorin made them to look inward for the solution to the problems. The colonial administration therefore had to moderate its intention to forcefully subjugate the Balogun to the control of the Emir. The British realized that the Balogun too must be carried along, if only the British intended to succeed in their control of Ilorin. It was for this purpose that the government decided to award some of the Balogun, Second Class II chieftaincy status, while the Emir was awarded first class status. NAK/ILO/PROF/1/1 Report No 6 January 1903. Even with the recognition accorded the Balogun by the British which was in contrast with their original plan to forcefully impose the Emir on them as a sole administrator, frictions between the Balogun and the Emir on the operation or implementation of colonial policies in Ilorin continued to generate crisis between them and their followers. The reaction of the other Balogun and in fact, that of the majority of the people of Ilorin was premised on the fact that the colonial administration had decided to confer on the Emir the status of a sole authority in Ilorin, in which all the other political institutions in the Emirate would be responsible to him. This was done by referring all matters relating to the Emirate only to the Emir and the position taken by the Emir on them was supported by the colonial administration. Added to this was the fact that all instructions by the colonial administration were only passed through the Emir. This policy of the colonial administration negates the traditional structure in Ilorin Emirate whereby collective leadership rather than sole authority was the system that had sustained Ilorin Emirate as an entity. Through the natural process of political development and changes in Ilorin Emirate, the Emir only reigned, while the Balogun ruled NAK/SNP/5173/1907 Report on Ilorin Prof. 1906.

The efforts of the colonial administration to forcefully impose the Emir as a sole authority, naturally generated protracted reactions such as the uncooperative attitudes of the Balogun and people of Ilorin against the British. This situation explains why the colonial administration continued to change its policy of administration in Ilorin until the other traditional political institutions in the Emirate were effectively integrated into its colonial system.

By 1908 the colonial government had concluded its plans to reorganize the territories under Ilorin Emirate. The territories were grouped into eighteen (18) units called districts. The Districts were Akanbi, Afon, Owode, Ajasse, Igbaja, Offa, Otun, Omu, Osi, Shonga, Share, Iponrin, Lanwa, Ejidongari, Oloru, Paiye, Malete and Onire Elphinstone, K. V. Vol. III pg.9

The restructuring of Ilorin Emirate was designed to make the Emir the most influential and powerful in the Emirate. Perhaps because the Emir was not consulted before the Colonial government made the new structural arrangement public, the Emir, for the first time in the history of colonial administration in Ilorin, openly expressed resentment against the colonial policy. The Emir also expressed fears that some of his own appointees, as Daudu, would also lose their position Elphinstone, K. V. Vol. III pg.9

It actually took the colonial administration some time to convince the Emir that the administrative reforms were to his advantage. With the reorganization, the powers and influence of the Balogun were further eroded.

Expectedly, the new arrangement was considered by the Balogun as another negative policy of the colonial government aimed at reducing their powers and influence, and in fact meant to subject them to the control of the Emir. Even with this knowledge, the Balogun could not readily organize any resistance against the British authority at this time. The manner in which two of them were humiliated was still very much fresh in their memories.

However by coincidence, some of the places grouped into districts still fell within the influence of the respective Balogun. Some of their original appointees were retained as District Heads of some of the newly created districts. However, the appointed district heads were quickly made to know that they were not officers of the colonial government but subjects of the Emir and on no account should any of them relate directly with the Colonial Resident. Elphinstone, K. V. Vol. III, pp.9- 18

They were made to know that they were totally responsible to the Emir either by appointment or by operation and no more to the Balogun.

The administrative restructuring created new power relations among and between the political office holders. Both the Emir and the Balogun appreciated the enormous benefits they derived from the administration of the fiefs. Apart from the fact that fiefs served as the main source of their personal economic wealth, it was 
also a good source of their influence and powers. The adjustments, both human and structural that followed the creation of the Districts, naturally opened a new phase of inter group relations in Ilorin Emirate. While some of the old fief heads were lucky to be among the newly appointed District Heads, some others were not so lucky. The boundary adjustment of the old fief structure to that of the new District was also important. Places that had not been under a single authority were brought together under a District Head. Coincidentally, some of the fief appointees of the respective Balogun were either retained or appointed among the new District Heads.

The Balogun had to console themselves with the fact that some of their original appointees were still retained as District Heads. They were however also fully aware of the fact that their traditional control and influence in the newly created districts were no more. Certainly, because the Emir himself was not involved in the formulation of the colonial policy that created the districts, he could not readily appreciate the enormity of the powers given him by the colonial government. He maintained a measure of the traditional process of administration by relating with some of the newly appointed district heads through their original benefactors, the Balogun, and he requested the Balogun to appoint successors into any vacant stool of a District Head.

\section{The accommodation of more interest group in the Emirate Council}

The limited achievement recorded by the colonial administration to ensure peaceful acceptance of its rule through the use of force, made the colonial administration to continuously change its policy until, it recognized the indigenous ethnic balancing in the administrative structure of the Emirate. The implementation of the recommendations of the Palmer's Commission of Enquiry of 1913, wherein, more Yoruba were brought into the Emirate council, with the inclusion of Aare and the Baba Isale, both of whom were from Aare Afonja's family, actually provided the atmosphere for the colonial administration to record peace in Ilorin.

The establishment of British colonial rule in Ilorin can therefore be said to have generated two contradictory historical issues. The first was the disunity in the relations between the indigenous political ruling class, which the British exploited to their advantage and the second was the recognition by the British, of the need for ethnic balancing in administering Ilorin.

\section{Conclusion}

The experiences derived from British Colonial rule in Ilorin can be summarized as creating the atmosphere for another phase of power struggle between the indigenous ruling classes in Ilorin, justify the importance of ethnic balancing in heterogeneous community as Ilorin and illustrate the limited achievements that can be made with the use of force.

The restructuring of the political powers and functions of the indigenous institutions to accommodate British has remained the source of problems between the Chieftaincy institutions in Ilorin. Even though the treachery of Emir Sulyman both to the members of his emirate council, to Bida and the Caliph at Sokoto, did not catch up with him in his life time, his linage has not been Emir in Illorin since his demise in 1915.

\section{References}

[1] Elphinstone K.V.,Gazetteers of the Northern Provinces of Nigeria Vol. III the Central Kingdom, p. 9.

[2] Hogben S.J, the Muhammedan Emirates of Nigeria, (Oxford University Press 1966), pp. 161 - 163.

[3] NAK/SNP/15/11 Carnegie to H. C. July 1900.

[4] NAK/SNP/15/11 P. Dwyer to H. C. August 1900.

[5] NAK/SNP/15/11 H. C. to P. Dwyer, September 1900.

[6] NAK/ILO/PROF/1/1 Report No 6 January 1903.

[7] NAK/SNP/5173/1907 Report on Ilorin Prof. 1906.

[8] Obaro Ikime, the fall of Nigeria, Heinemann Educational Books Ltd. 1977 P. 129.

[9] Omoiya,S.Y. "The Life and Times of BalogunInakoju Ali 1827 -1910" B.A. Long Essay. Submitted to University of Ilorin.1986 Pp $33-35$.

[10] Omoiya,S.Y “The Impact of Colonial Administration on Political Insitutions in Ilorin 1897 - 1960”,M.A. Ibadan.1988 pp. 32 - 33.

[11] Oral evidence obtained from Alh. Saliu Dauda, Trader and Cleric .78yrs.

[12] Oral evidence obtained from Alh. Sule Salawu, an Islamic Cleric and Trader Aged 87years.

[13] The Holy Quran, Chapter 8, verse 65, Reviewed and Edited by Ismail International Organization. 1997. 